\title{
SUSTAINABILITY-DISCLOSURES AND FINANCIAL PERFORMANCE: SHARIAH COMPLIANT VS NON- SHARIAH-COMPLIANT INDONESIAN FIRMS
}

\author{
Mudeer Ahmed Khattak ${ }^{1}$, Mohsin Ali ${ }^{2}$ and Aman Khan Burki ${ }^{3}$ \\ ${ }^{1}$ Universiti Kuala Lumpur, Malaysia, mudeerkhattak@gmail.com \\ ${ }^{2}$ Taylor's University, Malaysia, mohsin.ali121@gmail.com \\ ${ }^{3}$ INCEIF, Malaysia, amanburki@hotmail.com
}

\begin{abstract}
We investigate the impact of sustainability-performance disclosure (SPD) on firm performance on a cross-industry sample of 71 firms over the period 2011-2018. We also compare the relationship between shariah-compliant firms (SCFs) and non-shariahcompliant firms(NSCF). To control for possible issues of unobserved heterogeneity, endogeneity and autocorrelation, we use the system generalized method of moments approach. We found that disclosure of sustainability performance increases a firm's financial performance. Firms which disclose information on their sustainability practices were found to have higher earnings on assets and equity, which clearly supports the argument of information asymmetry. In the comparison of shariahcompliant and non-shariah-compliant firms, it was found that SCFs are at an advantage by being shariah compliant and that disclosure of sustainability performance increases the financial performance of such firms, whereas for non-shariah-compliant firms, the impact was found to be negative. One of the main findings from the research is that while firms' involvement in corporate sustainability activities is encouraged, they also need to disclose any related information to their stakeholders, general public to capitalise on this investment, in return for a good reputation and consider going shariah complaint. Our study further recommends that the management of firms in Indonesia should focus on shariah compliance and consider sustainability-practice and sustainability-performance disclosures with a positive mindset, recognising them as means of gaining an advantage rather than as an obligation.
\end{abstract}

Keywords: Sustainability, Disclosure, Performance, Indonesia, Shariah compliance. JEL Classification: M14; Q01; A13.

Article history:

Received : October 5, 2019

Revised : June 11, 2020

Accepted : August 27, 2020

Available online : November 25, 2020

https://doi.org/10.21098/jimf.v6i4.1087 


\section{INTRODUCTION}

\subsection{Background}

Debate on the impact of sustainability activities on businesses has been increasing, along with the growing awareness of these amongst the public and other stakeholders. The focus of attention has been on the impact on society and the environment. The importance of sustainable practices can be understood by observing the increasing global trend in ESG performance disclosures. Among the largest 250 corporations in the world, fewer than $80 \%$ reported their sustainability performance in 2008 (KPMG, 2008), a figure which currently stands at 93\% according to KPMG (2017).

Firms that perform better are expected to contribute more to society and engage more in sustainable practices. However, the question of how such practices affect firms' financial performance remains inconclusive (Clark \& Viehs, 2014; Margolis, Elfenbein, \& Walsh, 2009). It is traditionally believed that investment above the legally binding minimum levels leads to additional costs to business, which result in weakened firm performance. Moreover, Kim and Lyon (2015) argue that "the entire environmental regulatory paradigm is built around the idea that firms must be forced to make environmental improvements, because they would otherwise find them costly or unprofitable, and thus not undertake them on their own." Many researchers have recently argued in favour of sustainability activities and concluded that investment in these enhances firms' financial performance, hence increasing their overall value (Fatemi, Fooladi, \& Tehranian, 2015; Malik, 2015; Porter \& Kramer, 2011). There are certain benefits of voluntary disclosures, which include a reduction in information asymmetry and adverse selection costs (Healy \& Palepu, 2001). As argued by Jensen (2002), firms can maximise their long-term value by considering the interests of all their stakeholders; sustainability practices can also increase their overall reputation by strengthening relationships with their stakeholders. Such information disclosure also gives investors extra awareness, which ultimately results in greater investor gains (Merton, 1987). Moreover, Healy and Palepu (2001) argue that firms' management can exploit information disclosure for their own benefit to cover up their bad performance. Merkl-Davies and Brennan (2007) term this 'impression management', the process by which managers exploit information asymmetries by engaging in biased reporting. In light of the contrasting evidence in the literature, it is hard to expect a clear definition of the relationship between SPD and firms' financial performance. We further focus on the shariah compliance of firms and explore whether this helps in gaining greater investment advantages in sustainability practices. The absence of research on this topic is unfortunate, particularly since Islamic finance has been pitched as an alternative to the conventional system by various strong advocates (see, for example, Mirakhor, 2010). The increasing acceptance of Islamic finance makes it necessary to examine whether shariah compliance matters.

Considering the above arguments, the relationship between SPD and firms' financial performance remains inconclusive. Previous studies have mainly used corporate social responsibility scores to study the relationship, or have employed the zero-one method (Mohammed et al., 2016; Yeganeh \& Barzegar, 2014), which only indicates if firms have disclosed any information on their sustainability practices or not. Our study, however, avoids the yes/no approach and instead uses 
disclosure scores ranging from 0-100, with 100 representing the highest disclosure performance. Our study contributes to the literature in many ways: first, it covers a large sample of 71 listed companies in Indonesia. Second, it uses disclosure scores instead of the $0 / 1$ method. Third, it is the first study which contributes to the literature on the impact of sustainability practices by comparing shariahcompliant and non-shariah-compliant firms. Fourth, it takes into account the methodology and regression analysis by using a sophisticated dynamic panel data estimator, the system generalized method of moments, to control for possible issues of heterogeneity across the sample, as well as serial auto-correlation and endogeneity concerns which have been mainly neglected in previous studies.

\subsection{Objective}

We intend to investigate the impact of sustainability-performance disclosure (SPD) on firm performance based on a cross-industry sample of 71 Indonesian firms over the period of 2010-2018 and employing Bloomberg's disclosure scores. We further explore if shariah compliance matters in the relationship between SPD and firms' financial performance. It should be noted that the sample size in our analysis was driven by the availability of SPD data in Indonesia. The firms in our dataset belong to different industries (see Appendix A, Panel B). Furthermore, to control for potential problems in our panel data settings, such as industry heterogeneity, serial autocorrelation and endogeneity, we use a sophisticated dynamic panel estimator, the system generalized method of moments. After controlling for these potential issues, firm- specific controls and country-specific characteristics, we found a positive impact of SPD on firm value, indicating that disclosure of sustainability practices enhances firms' value by increasing their reputation. Shariah-compliant firms tend to benefit from SPD in terms of higher financial performance, unlike non-shariah-compliant firms, where the impact is found to be negative.

The remainder of the article is structured as follows. The following section

gives a summary of the relevant literature on the relationship between SPD and firms' financial performance, followed by the data and methodology section, which describes the data sources, econometric modelling and the variable specification. Subsequently, the results are explained in the empirical analysis section, which is followed by discussion of the results. The final section provides the conclusion and policy implications of the research.

\section{RELEVANT STUDIES}

\subsection{Background Theory}

Several researchers have attempted to address the impact of sustainabilityperformance disclosure; however, the nature of the relationship remains unclear. Margolis and Walsh (2001) explored 80 studies and concluded that 53\% of them provided evidence of a positive relationship, $24 \%$ showed no association, $19 \%$ provided obtained mixed results and only $4 \%$ found a negative relationship. Siregar and Bachtiar (2010) and Teoh et al. (1998) found that SPD led to better financial performance, while researchers reached inconsistent results (Fauzi et al., 2007; Belkaoui \& Karpik, 1989). Furthermore, Naser et al. (2002) also found a positive 
relationship between the extent of SPD and financial performance, concluding that SPD might be a strategic option for businesses. They further found that positive information disclosure about employees might attract potential other employees, which would enhance firms' overall productivity and performance.

Shariah-compliant firms are different in terms of their characteristic of following strict shariah screening in order to remain shariah compliant and not engage in certain activities beyond a certain threshold, such as debt (Azmi, Anwer, Mohamad, \& Shah, 2019). Considering the different nature of these firms, we investigate if shariah compliance matters in the shaping the relationship between SPD and financial performance.

\subsection{Previous Studies}

Exploring the manufacturing industry of Indonesia, Kartadjumena, Hadi and Budiana (2011) studied SPD and firms' financial performance and found a positive relationship between SPD and firms' earning per share. Yahya and Bargebar (2014) used economic, social and environmental dimensions to explore firms listed on the Iran stock exchange and found a significant impact of SPD on their financial performance.

It is also argued that such disclosure can also bring reputational benefits to businesses. For instance, Merkl-Davies and Brennan (2007) argue that firms might use SPD to gain a good reputation by adopting impression management strategies. This might be in reaction to negative institutional outcomes driven by management self-interest. Eccles, Ioannou, and Serafeim (2014) argue that firms' management might invest in sustainability activities and disclose information on these for personal gain, while Healy and Palepu (2001) found that firms' management could use such disclosures to justify or mitigate their poor performance.

On the other hand, sustainability investment is argued to be an additional cost for business, which can lead to a negative relationship between SPD and financial performance. In 1970 Milton Friedman argued that such activities are actually a cost, and called them unjust taxation. He further argued that firms contribute to society by maximising their profits, a relationship which was recently confirmed by Villiers and Van Staden (2011), who found a negative relationship between environmental disclosure and financial performance. This negative relationship was confirmed by Goel and Thakor (2016), who found that the managers of investment in ESG activities gained competitive advantage over other firms by building their reputation. Iheduru et al. (2019) examined selected firms in Nigeria and found that SPD had a negative impact on returns on investments. Considering the conflicting views described above, it remains unknown what the situation is in Indonesia.

Taking into account the evidence of the opposing directions of the relationship, research remains inconclusive. Therefore, it is difficult to expect a clear direction of the relationship between SPD and firms' financial performance. 


\section{DATA AND METHODOLOGY}

\subsection{Data}

We investigated the impact of SPD on firm performance using firm-level data sourced from Bloomberg and the macro-economic characteristics of Indonesia sourced from the World Bank's world development indicators. The dataset was driven by the data availability on SPD. The initial dataset was from 2006; however, due to limited data points, the initial years were dropped from the final dataset. The information on the shariah compliance of these firms was taken from the reports of Indeks Saham Syariah Indonesia (ISSI) ${ }^{1}$, which issues reports on the listing and delisting of firms based on their shariah compliance. A table showing the number of shariah-compliant firms in each year can be found in appendix B. Our dataset consists of the most recent data, from 71 listed firms that have reported SPD data for the 9 years from 2010 to 2018. In order to explore the difference in the relationship for shariah-compliant and non-shariah-compliant firms, the dataset was reduced to 2011-2018. This was because information on shariah compliance is only available from 2011 onwards.

\subsection{Model Development}

$$
F_{-} P_{\text {erf }}=\beta_{0}+\beta_{1} F_{-} \operatorname{Per}_{i t-1}+\beta_{3} S P D_{i t}+\beta_{4} X_{i t}+\beta_{5} M c_{j t}+\varepsilon_{i t}
$$

where $F_{-}$Perf $_{\text {it }}$ indicates the financial performance of firm i in time $t$; F_Per ${ }_{\text {it- } 1}$ denotes the one-period lag dependent variable; SPD stands for sustainabilityperformance disclosure; $X$ is the vector of firm-level control variables; $M c$ shows the controls for country-specific indicators; and $\varepsilon_{\mathrm{it}}$ is the error term. The above model was modified with a dummy interaction term to explore any possible difference in the relationship between shariah-compliant and non-shariah-compliant firms. The dummy variable (SCF) takes the value of 1 if the firm is shariah compliant, and 0 otherwise.

$$
\begin{aligned}
& F_{-} P_{e r f}=\beta_{0}+\beta_{1} F_{-} P_{i t} \operatorname{Per}_{i t-1}+\beta_{3} S P D_{i t}+\beta_{4}\left(S P D_{i t} * S C F\right)+\beta_{5} S C F+ \\
& \beta_{6} X_{i t}+\beta_{7} M c_{j t}+\varepsilon_{i t}
\end{aligned}
$$

$\mathrm{SPD}_{\text {it }}{ }^{*} \mathrm{SCF}$ indicates the interaction dummy in the model. The significance of the dummy interaction term indicates the difference in the relationship for SCF and NSCF.

\subsection{Method}

Considering the complex nature of our dataset, the possible presence of unobserved heterogeneity, endogeneity and autocorrelation among the error terms and the explanatory variables cannot be neglected. The presence of individual heterogeneity, heteroscedasticity, autocorrelation and endogeneity of the dataset was tested by applying the Breush-Pagan test, the Wald test of heteroscedasticity,

1. https://www.syariahsaham.com/p/list-saham-issi.html 
the Wooldridge test, and the Durbin-Wu-Hausman test (augmented regression test) for endogeneity ${ }^{2}$, respectively. These tests rejected the null hypotheses of non-existence of these issues at the $1 \%$ and $5 \%$ levels of significance (see Appendix $\mathrm{B}$, Table A). To avoid these concerns, we adopted generalized method of moments (GMM) (see also Berger et al., 2009; Noman et al., 2017; Noman, Gee, \& Isa, 2018).

GMM was first introduced by Arellano and Bond (1991) and is also known as difference GMM, as it considers the within-difference of variables in order to control for possible issues in the data, as discussed above, that traditional panel estimators such as ordinary least squares, random effects and fixed effects estimators fail to address. Blundell and Bond (1998) proposed an efficient estimator which used within-difference, together with levels known as system GMM estimators. GMM is known to work best when the number of cross-sections is larger than the number of times series (i.e. $\mathrm{N}>\mathrm{T}$ ), and especially when the dependent variable is persistent (past values may be impacting on present values of financial performance), as in our settings.

\subsection{Variable Specification}

\section{Dependent variable: firms' financial performance}

We use firms' return on assets as a proxy for their performance. This is estimated as net income divided by total assets. One might argue that for listed firms Tobin's $\mathrm{Q}$ is often used. However, following Bartlett and Partnoy (2018), who argue that "the original version of q morphed into the simplified market-to-book ratio version that law and finance scholars regularly use today to examine regulatory policy, corporate governance, and other economic phenomena. Whereas macroeconomists rejected this simplistic version of $q$ because of measurement error problems, law and finance scholars embraced it as a proxy for firm value", we use ROA, which is widely employed as a proxy for firms' financial performance in the literature on sustainability-performance (Cho, Chung, \& Young, 2019; Weber, 2017; Joo et al., 2011). ROA is measured as the ratio of net income to total assets.

\section{Main independent variable: sustainability-performance disclosure}

We employed Bloomberg's ESG disclosure scores, which are aggregated scores for environmental, social and governance scores at the firm level. The scores range from $0-100$. These variables have been used previously in research on corporate social responsibility and disclosure performance, and Bloomberg's disclosure scores have previously been used by Eccles, Serafeim and Krzus (2011); Utz and Wimmer (2014); Qiu et. al. (2016) and Bernardi and Stark (2018), amongst others.

\section{Controls}

In order to control for different factors that might influence a firm's financial performance, we controlled for different firm-level characteristics of firm size. It is argued that larger firms perform better and can earn higher profits. Size is argued to be an important determinant, as larger firms tend to have more resources and greater access to funds for investment in sustainability practices (Baumann-Pauly

\footnotetext{
2. https://www.stata.com/support/faqs/statistics/durbin-wu-hausman-test/
} 
et al., 2013; Davison \& Skerratt, 2007). Firm size is proxied by the log of firms' total assets. Moreover, firms with a higher capitalisation ratio are argued to have better performance as they can benefit from their greater capitalisation. This was controlled by employing the ratio of firms' equity to assets. Besides firms' capitalisation and size, we also controlled for their debt level. This was proxied by firms' total debt (Beck, Frost, \& Jones, 2018). Several studies have investigated research and development expenses as one of the determinants of financial performance and found a positive association (Horváthová, 2010). Therefore, we controlled for research and development (R\&D) intensity, proxied by research costs and firm development. Furthermore, in order to control for the impact of inflation on firms' financial performance, we used inflation rates sourced from the World Bank's world development indicators. Besides the inflation rate, a country's economic growth can also impact firm performance. For this, we also controlled for national GDP growth, also sourced from the World Bank's world development indicators. For robustness purposes, we also included GDP per capita. To avoid issues of multicollinearity, GDP per capita and GDP growth cannot be put into the same model due to their high correlation (see Table 2); we replaced GDP growth with GDP per capita income. Second, since GDP per capita was adjusted for inflation, we also replaced inflation and used GDP per capita.

\section{RESULTS AND ANALYSIS}

\subsection{Summary Statistics and Correlation Matrix}

Table 1 presents the summary statistics of the variables used in the regression analysis. Having a strong balanced panel means the ROA for the firms in our dataset is 8.21 , with a standard deviation of 12.31 . The ROA ranges from -92.47 to 49.07. For SPD, the mean and standard deviation are 20.85 and 12.11 , in the range from 5.78 to 54.13 . Firms' mean total assets are $2.14 \mathrm{e}+07$, with standard deviation of $3.84 \mathrm{e}+07$.

Table 1.

Summary Statistics

\begin{tabular}{lccccc}
\hline \multicolumn{1}{c}{ Variable } & Obs & Mean & Std. Dev. & Min & Max \\
\hline ROA & 548 & 8.207146 & 12.31666 & -92.4734 & 49.0702 \\
SPD & 548 & 20.85645 & 12.10766 & 5.7851 & 54.1322 \\
TA & 548 & $2.14 \mathrm{e}+07$ & $3.84 \mathrm{e}+07$ & 49.0274 & $3.45 \mathrm{e}+08$ \\
Cap_R & 539 & 18.74218 & 20.72002 & -.0257 & 91.8969 \\
lnDebt & 495 & 12.55248 & 4.338088 & -1.777265 & 18.26886 \\
GDPc & 478 & 4.146799 & .4469426 & 3.645004 & 4.82944 \\
R\&D & 546 & 7343.71 & 40905.35 & 0 & 528000 \\
GDPG & 478 & 5.41893 & .5186785 & 4.876322 & 6.223854 \\
Inflat & 478 & 5.117159 & 1.162468 & 3.525805 & 6.412513 \\
\hline
\end{tabular}


Since we have firms from different industries in our dataset, a wide variation in the total assets (TA) of firms is expected. The mean firm capitalisation ratio stands at 18.74, with standard deviation of 20.72, while firms' capitalisation ratio ranges from-0.316 to 91.9. The mean for the R\&D expenditure of firms is 7343.7, with standard deviation of 40905.35 and the values of such expenditure ranging from 0 to 528000. All the absolute values are in USD millions, apart from total debt, while ROA and Cap_R are ratios. Changes in Inflat and GDPG are shown in percentages.

Table 2.

Correlation Matrix

\begin{tabular}{lccccccccc}
\hline & ROA & SPD & TA & Cap_R & lnDebt & Inflat & GDPG & R\&D & GDPc \\
\hline ROA & 1 & & & & & & & & \\
SPD & 0.00987 & 1 & & & & & & & \\
TA & 0.0191 & $0.275^{* * *}$ & 1 & & & & & & \\
Cap_R & $-0.311^{* * *}$ & 0.0405 & 0.0142 & 1 & & & & & \\
lnDebt & 0.0285 & $0.146^{* *}$ & $0.485^{* * *}$ & $0.103^{*}$ & 1 & & & & \\
Inflat & -0.0394 & $-0.103^{*}$ & -0.0441 & -0.0123 & -0.0165 & 1 & & & \\
GDPG & $0.272^{* * *}$ & $-0.209^{* * *}$ & -0.0934 & -0.0845 & -0.0361 & -0.0409 & 1 & & \\
R\&D & 0.0776 & $0.0994^{*}$ & $0.256^{* * *}$ & -0.0642 & $0.100^{*}$ & 0.0572 & -0.0424 & 1 & \\
GDPc & $0.272^{* * *}$ & $-0.198^{* * *}$ & -0.0877 & -0.0819 & -0.0351 & $-0.125^{* *}$ & $0.995^{* * *}$ & -0.0479 & 1 \\
\hline${ }^{*} p<0.05,{ }^{* *} p<0.01, * * * * 0.001$ & & & & & & & & &
\end{tabular}

Table 2 shows the pairwise correlation between the variables. The correlation coefficient ranges from -0.316 to 0.995 , with the highest correlation found between GDPG and GDPc. GDPG and Inflat were replaced by GDPc in robustness, together with R\&D. Therefore, no high levels of correlation were found between the variables used in the same model, meaning the issue of multicollinearity was rejected.

\subsection{Level of disclosure in Indonesia}

Figure 1 shows the trend of sustainability-performance disclosure in Indonesia through the sampling period. It is evident from the figure that there is a clear upward trend of disclosure among the firms. The average disclosure score in 2010 was around 16, which had increased to 24 by the end of 2018. 


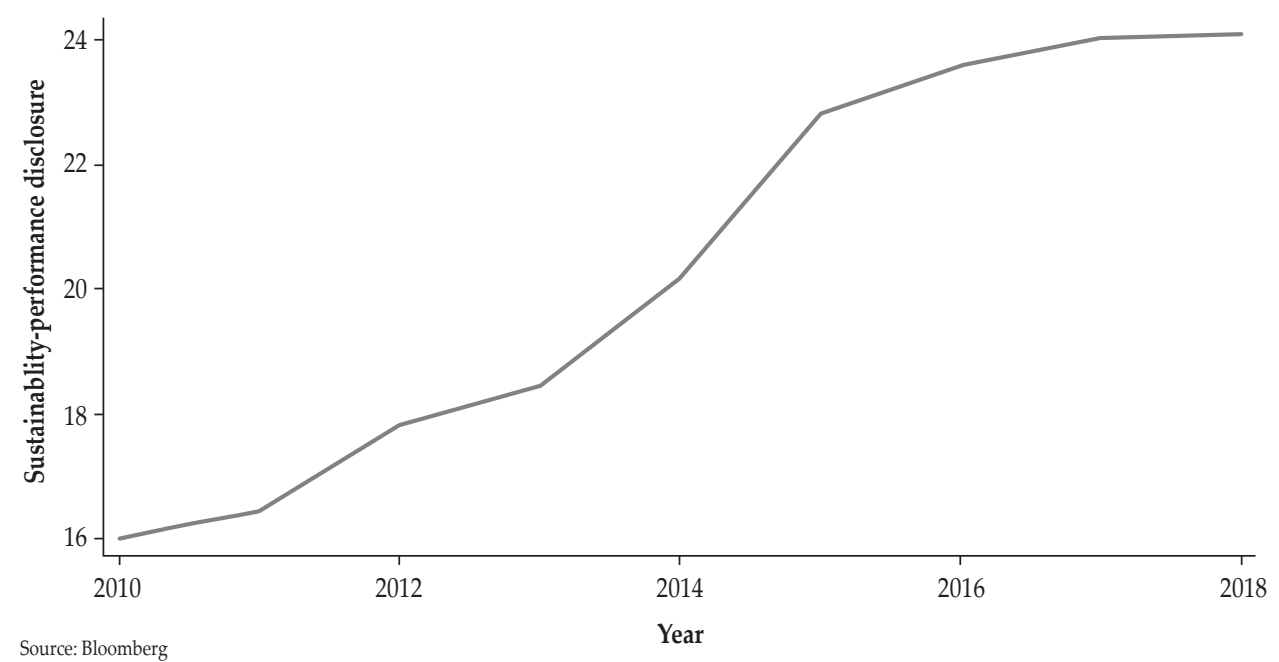

Figure 1.

Trend of Disclosure in Indonesia

\subsection{Results and Analysis}

Using Eqs 1 and 2, we estimated five different models to strengthen our analysis. Model (1) and Model (2) present the results with firm-specific variables, and firmand country-level variables, respectively. Model (3) is a modification of Model (2), with year dummies to control for technological progress in the country. Since our data include firms from different industries, we further modified model (2) by adding industry-specific affects to control for industrial heterogeneity to Model (4). Model (5) shows the results with time-fixed dummies and industry-fixed effects.

We employed system GMM to cater for the potential issues of unobserved heterogeneity, endogeneity and autocorrelation among the error terms and the explanatory variables. Our dependent variable is ROA, as a proxy for firms' financial performance. Our main results do not differ with the changes in model specifications. The estimated models fit well into the panel settings and show stable coefficients. We treated the independent variables as strictly exogenous, except for sustainability-performance disclosure. The reason for treating SPD as an endogenous variable is that its current and past values are not correlated with the current error term $(\varepsilon)$. The insignificant values of the Hansen tests indicate that the instruments are not correlated with the error terms, which justifies their validity. In other words, our model does not have an overidentification of instruments problem and is correctly specified. Moreover, the insignificant values of the Arellano-Bond (AR-2) tests show that the null hypothesis of "No-Autocorrelation" is not rejected, which shows further consistency of the estimators used in our models. 


\subsubsection{Impact of SPD on firms' financial performance}

Table 3 presents the results of our main regression analysis. The lag dependent variable is found to be consistently positive throughout the different specifications. This validates our use of a dynamic estimator to control for the persistence in the dependent variable. The coefficients of SPD are consistently highly significant and show a positive impact on firms' financial performance. This indicates that firms which have better disclosure performance tend to have better financial performance. This is in line with the findings of Beck, Frost, and Jones (2018) and Cahan, De Villiers, Jeter, Naiker, and Van Staden, 2016), who also found evidence that SPD can be indicative of actual financial performance. Firms that voluntarily issue sustainability-performance reports tend to have higher sustainability performance compared to their counterparts (Dhaliwal, Li, Tsang, \& Yang, 2011). This can be explained by the argument that disclosure is determined by managerial decisions in order to maintain their reputation (Aerts, 2005; Barkemeyer et al., 2014). This is an indication of the gains made by information disclosure, whereby firms can benefit from disclosing information on their activities, thus strengthening their reputation, leading to higher performance.

The results for firm size (Ln_ta) and the capitalisation ratio were found to be consistent and positively significant. This suggests that larger and better capitalised firms tend to perform better. This finding is in line with those of Cahan et al. (2016). The coefficients for firms' total debt were found to be consistently negatively significant, which indicates that higher debt levels result in lower financial performance. The impact of the inflation rate on firms' financial performance was found to be significant and negative. This shows that firms facing higher inflation rates achieve lower financial performance. National GDP growth was found to be positively significant in Models 2, 3 and 4, which suggests that higher GDP growth encourages firm performance. Surprisingly, in Model 5 the impact of GDP growth becomes negative when controlled for time dummies and industry-fixed effects. This might be due to the difference in the impact of GDP growth across different industries in our sample.

Table 3.

Impact of SPD on Financial Performance

\begin{tabular}{lccccc}
\hline & -1 & -2 & -3 & -4 & -5 \\
& M1 & M2 & M3 & M4 & M5 \\
\hline L.ROA & $0.6024^{* * *}$ & $0.2979^{* * *}$ & $0.3134^{* * * *}$ & $0.1872^{* * *}$ & $0.1773^{* * *}$ \\
& {$[0.000]$} & {$[0.000]$} & {$[0.000]$} & {$[0.000]$} & {$[0.000]$} \\
SPD & $0.0077^{* * *}$ & $0.0268^{* * *}$ & $0.0327^{* * *}$ & $0.1598^{* * *}$ & $0.1212^{* * *}$ \\
& {$[0.006]$} & {$[0.000]$} & {$[0.002]$} & {$[0.000]$} & {$[0.000]$} \\
Ln_ta & $1.3099^{* * *}$ & $2.6351^{* * *}$ & $2.6336^{* * *}$ & $2.8086^{* * *}$ & $2.9249^{* * *}$ \\
& {$[0.000]$} & {$[0.000]$} & {$[0.000]$} & {$[0.000]$} & {$[0.000]$} \\
Cap_R & $0.0033^{*}$ & $0.0252^{* * *}$ & $0.0293^{* * *}$ & $0.0288^{*}$ & $0.0446^{* * *}$ \\
& {$[0.085]$} & {$[0.000]$} & {$[0.000]$} & {$[0.077]$} & {$[0.000]$} \\
lnDebt & $-1.1621^{* * *}$ & $-2.2465^{* * *}$ & $-2.2473^{* * *}$ & $-2.6485^{* * *}$ & $-2.7503^{* * *}$ \\
& {$[0.000]$} & {$[0.000]$} & {$[0.000]$} & {$[0.000]$} & {$[0.000]$} \\
\hline
\end{tabular}


Table 3.

Impact of SPD on Financial Performance (Continued)

\begin{tabular}{lccccc}
\hline & $\mathbf{- 1}$ & $-\mathbf{2}$ & $-\mathbf{3}$ & -4 & -5 \\
& M1 & M2 & M3 & M4 & M5 \\
\hline Inflat & & $-0.4217^{* * *}$ & $-1.6764^{* * *}$ & -0.0151 & $-0.6072^{* * *}$ \\
& & {$[0.000]$} & {$[0.000]$} & {$[0.923]$} & {$[0.000]$} \\
GDPGR & & $4.2390^{* * *}$ & $0.5970^{* * *}$ & $4.8503^{* * *}$ & $-1.1378^{* * *}$ \\
& & {$[0.000]$} & {$[0.000]$} & {$[0.000]$} & {$[0.000]$} \\
Constant & $-1.9927^{* * *}$ & $-26.5307^{* * *}$ & 0.0000 & $-31.7125^{* * *}$ & 0.0000 \\
& {$[0.000]$} & {$[0.000]$} & {$[]$.} & {$[0.000]$} & {$[]$.} \\
\hline \multicolumn{1}{c}{ Industry Fixed Effects } & No & No & No & Yes & Yes \\
\hline \multicolumn{1}{c}{ Time Dummies } & No & No & Yes & No & Yes \\
\hline Observations & 432 & 369 & 369 & 369 & 369 \\
Instruments & 67.0000 & 67.0000 & 67.0000 & 32.0000 & 51.0000 \\
Groups & 67.0000 & 67.0000 & 67.0000 & 67.0000 & 67.0000 \\
AR(1) & 0.0326 & 0.0710 & 0.0657 & 0.0595 & 0.0882 \\
AR(2) & 0.6310 & 0.6734 & 0.7005 & 0.7939 & 0.6036 \\
Hansen (p-Val) & 0.4266 & 0.6800 & 0.3757 & 0.1842 & 0.1568 \\
\hline
\end{tabular}

$p$-value in parentheses

" $p<0.1,{ }^{* *} p<0.05, " * * 0<0.01$

\subsubsection{Shariah-compliant vs non-shariah compliant firms}

This section explores the possible differences in the relationship between shariahcompliant and non-shariah compliant firms by estimating the modified model in equation 2 . Table 4 presents the results regarding the possible difference in the relationship. The dummy (SC) is consistently negative, indicating the overall lower financial performance of shariah-compliant firms. The interaction term (SPD\#SC) is found to be positive and is line with previous findings. This shows that firms that are shariah compliant tend to benefit from SPD in terms of stronger financial performance. On the other hand, interestingly, it was found that after the inclusion of the dummy interaction term in the model, the sign of the SPD coefficient changed in the opposite direction. The SPD shows that for non-shariah compliant firms, the impact is consistently highly significant, indicating a negative impact on firms' financial performance. This demonstrates that for firms that are nonshariah compliant, the impact of disclosure performance is negative. Considering the difference in the impact for shariah compliant and non-shariah compliant firms, it can be argued that non-shariah compliant ones are missing out on the greater benefits of SPD by staying non-shariah complaint. One of possible reason for the difference in the impact might be that shariah-compliant firms have a strict screening criterion, by which they abide by certain activity thresholds, so enjoy greater benefits (Azmi et al., 2019). Furthermore, it can be argued that customers prefer shariah-compliant firms with sustainable practices. The results regarding the control variables are consistent with the findings in Table 3, providing robustness for our earlier findings. 
Table 4.

Impact of SPD on Financial Performance (Shariah-compliant vs Non-Shariah Compliant Firms)

\begin{tabular}{|c|c|c|c|c|c|}
\hline & $\begin{array}{c}-1 \\
\text { M1 }\end{array}$ & $\begin{array}{c}-2 \\
\text { M2 }\end{array}$ & $\begin{array}{c}-3 \\
\text { M3 }\end{array}$ & $\begin{array}{c}-4 \\
\text { M4 }\end{array}$ & $\begin{array}{c}-5 \\
\text { M5 }\end{array}$ \\
\hline \multirow[t]{2}{*}{ L.ROA } & $0.5049^{* * *}$ & $0.2602^{* * *}$ & $0.2522^{* * *}$ & $0.1604^{* *}$ & $0.0376^{* *}$ \\
\hline & {$[0.000]$} & {$[0.000]$} & {$[0.000]$} & {$[0.048]$} & {$[0.040]$} \\
\hline \multirow[t]{2}{*}{ SPD } & $-0.4200^{* * *}$ & $-0.4403^{* * *}$ & $-0.3766^{* * *}$ & $-1.3788^{* * *}$ & $-1.2782^{* * *}$ \\
\hline & {$[0.000]$} & [0.000] & [0.000] & [0.000] & {$[0.000]$} \\
\hline \multirow[t]{2}{*}{ Lnta } & $1.6505^{* * *}$ & $2.5322^{* * *}$ & $2.3924^{* * *}$ & $2.8273^{* * *}$ & $3.2920^{* * *}$ \\
\hline & [0.000] & {$[0.000]$} & {$[0.000]$} & [0.003] & [0.000] \\
\hline \multirow[t]{2}{*}{ Cap_R } & 0.0015 & $0.0150^{* * *}$ & $0.0220^{* * *}$ & -0.0365 & 0.0126 \\
\hline & {$[0.770]$} & {$[0.000]$} & {$[0.000]$} & [0.259] & {$[0.174]$} \\
\hline \multirow[t]{2}{*}{$\operatorname{lnDebt}$} & $-1.5426^{* * *}$ & $-2.2507^{* * *}$ & $-2.0915^{* * *}$ & $-2.8521^{* * *}$ & $-3.2499 * * *$ \\
\hline & [0.000] & {$[0.000]$} & {$[0.000]$} & {$[0.001]$} & {$[0.000]$} \\
\hline \multirow[t]{2}{*}{ SC } & $-10.0841^{* * *}$ & $-8.5809^{* * *}$ & $-5.7329^{* * *}$ & $-42.3622^{* * *}$ & $-33.4258^{* * *}$ \\
\hline & {$[0.000]$} & [0.000] & [0.000] & [0.001] & [0.000] \\
\hline \multirow[t]{2}{*}{ SPD \# SC } & $0.5580^{* * *}$ & $0.5126^{* * *}$ & $0.4303^{* * *}$ & $1.7785^{* * *}$ & $1.5748^{* * *}$ \\
\hline & {$[0.000]$} & {$[0.000]$} & {$[0.000]$} & {$[0.000]$} & {$[0.000]$} \\
\hline \multirow[t]{2}{*}{ Inflat } & & $-0.6055^{* * *}$ & $-1.7735^{* * *}$ & 0.0161 & $-1.0144^{* *}$ \\
\hline & & {$[0.000]$} & {$[0.000]$} & {$[0.963]$} & {$[0.035]$} \\
\hline \multirow[t]{3}{*}{ GDPGR } & & $2.7392^{* * *}$ & $1.7961^{* * *}$ & $5.2896^{* * *}$ & $5.1977^{* * *}$ \\
\hline & & {$[0.000]$} & [0.000] & {$[0.003]$} & {$[0.000]$} \\
\hline & & & & {$[0.427]$} & {$[0.111]$} \\
\hline \multirow[t]{2}{*}{ Constant } & $5.4046^{* * *}$ & $-8.7598^{* * *}$ & 0.0000 & 1.7906 & 0.0000 \\
\hline & {$[0.000]$} & {$[0.000]$} & [.] & [0.901] & {$[]$.} \\
\hline Industry Fixed Effects & No & No & No & Yes & Yes \\
\hline Time Dummies & No & No & Yes & No & Yes \\
\hline Observations & 394 & 331 & 331 & 331 & 331 \\
\hline Instruments & 52.0000 & 52.0000 & 52.0000 & 30.0000 & 43.0000 \\
\hline )verall & 66.0000 & 66.0000 & 66.0000 & 66.0000 & 66.0000 \\
\hline Arellano-Bond:AR(1) & 0.0666 & 0.1276 & 0.1572 & 0.0215 & 0.0537 \\
\hline Arellano-Bond: AR(2) & 0.8559 & 0.7906 & 0.7097 & 0.8423 & 0.8964 \\
\hline Hansen Test (p-Val) & 0.5074 & 0.5449 & 0.5525 & 0.6510 & 0.0627 \\
\hline
\end{tabular}

$p$-value in parentheses

" $p<0.1,{ }^{* *} p<0.05,{ }^{, * *+} p<0.01$

\subsection{Robustness Tests}

We conducted several robustness checks to add credibility to our main results. The main baseline model was modified, with the inclusion of an additional firm-level control variable, namely research and development expenditure (R\&D). We also replaced GDP growth and inflation rate with GDP per capita income. We then 
re-estimated models 1-5. Table 5 presents the regression results for the robustness checks. The insignificant p-values of AR (2) and the Hansen tests again show the absence of autocorrelation and the validity of the instrument used in the models. The lower number of instruments than the number of groups adds further fitness to the model (Roodman, 2009).

The results shown in Table 5 were found to be consistent with our earlier results presented in Table 3. The lag dependent variable was found to be positive, as in our earlier results. The coefficients of SPD are positive and consistently significant. The coefficients of SPD are relatively stable, as they are in Table 3. This again suggests that firms with higher disclosure scores perform better financially. Firm size and the capitalisation ratio were found to have a positive impact on firms' financial performance. This again indicates that larger firms and those with a higher capitalisation ratio tend to perform better. The coefficient for firms' debt level shows that an increase in firms' leverage results in weaker financial performance, which is in line with our earlier findings. The extra firm-level variable, R\&D expenditure, was found to be consistently positively significant. Although the coefficients for R\&D are fairly small, the impact remains positive and cannot be neglected. One of the possible reasons behind the small R\&D coefficients might be their indirect impact on financial performance. The impact is not direct because higher performance cannot be achieved unless R\&D costs are capitalised and used for decision making. This suggests that firms that spend more on research and development activities tend to perform better. Firms with higher R\&D costs are able to make better decisions, which ultimately leads to overall better financial performance (Fatemi, Glaum, \& Kaiser, 2018). Finally, GDP per capita was found to be positive.

Overall, the results suggest that firms with greater SPD tend to have higher financial performance. This is consistent with the findings of Beck, Frost, and Jones (2018), Cahan, De Villiers, Jeter, Naiker, and Van Staden (2016), Siregar and Bachtiar (2010), Teoh et al. (1998), Fauzi et al. (2007), Belkaoui and Karpik (1989), Naser et al. (2002) and Hadi and Budiana (2011), who also found that firms with greater disclosures of their sustainability practices performed better.

Table 5.

Robustness Results for the Impact of SPD on Financial Performance

\begin{tabular}{|l|c|c|c|c|c|}
\hline & $\mathbf{- 1}$ & $\mathbf{- 2}$ & $\mathbf{- 3}$ & $\mathbf{- 4}$ & $\mathbf{- 5}$ \\
& $\mathbf{M 1}$ & $\mathbf{M} 2$ & $\mathbf{M 3}$ & $\mathbf{M} 4$ & M5 \\
\hline L.ROA & $0.6939^{* * *}$ & $0.4740^{* * *}$ & $0.6158^{* * *}$ & $0.1725^{* * *}$ & $0.1781^{* * *}$ \\
& {$[0.000]$} & {$[0.000]$} & {$[0.000]$} & {$[0.000]$} & {$[0.000]$} \\
SPD & $0.0146^{* *}$ & $0.0216^{* *}$ & $0.0242^{*}$ & $0.1161^{* * *}$ & $0.1188^{* * *}$ \\
& {$[0.013]$} & {$[0.022]$} & {$[0.073]$} & {$[0.000]$} & {$[0.000]$} \\
Ln_ta & $0.9781^{* * *}$ & $1.9585^{* * *}$ & $1.2040^{* * *}$ & $3.0001^{* * *}$ & $2.8696^{* * *}$ \\
& {$[0.000]$} & {$[0.000]$} & {$[0.000]$} & {$[0.000]$} & {$[0.000]$} \\
Cap_R & 0.0018 & $0.0242^{* * *}$ & 0.0051 & $0.0405^{* * *}$ & $0.0450^{* * *}$ \\
& {$[0.423]$} & {$[0.000]$} & {$[0.537]$} & {$[0.000]$} & {$[0.000]$} \\
\hline
\end{tabular}


Table 5.

Robustness Results for the Impact of SPD on Financial Performance (Continued)

\begin{tabular}{|c|c|c|c|c|c|}
\hline & $\begin{array}{c}-1 \\
\text { M1 }\end{array}$ & $\begin{array}{c}-2 \\
\text { M2 }\end{array}$ & $\begin{array}{c}-3 \\
\text { M3 }\end{array}$ & $\begin{array}{c}-4 \\
\text { M4 }\end{array}$ & $\begin{array}{c}-5 \\
\text { M5 }\end{array}$ \\
\hline $\ln$ Debt & $\begin{array}{c}-0.9050^{* * *} \\
{[0.000]}\end{array}$ & $\begin{array}{c}-1.7051^{* * *} \\
{[0.000]}\end{array}$ & $\begin{array}{c}-1.1041^{* * *} \\
{[0.000]}\end{array}$ & $\begin{array}{c}-2.8509^{* * *} \\
{[0.000]}\end{array}$ & $\begin{array}{c}-2.6980^{* * *} \\
{[0.000]}\end{array}$ \\
\hline $\mathrm{R} \& \mathrm{D}$ & $\begin{array}{c}0.0000^{* * *} \\
{[0.002]}\end{array}$ & $\begin{array}{c}0.0000^{* * *} \\
{[0.001]}\end{array}$ & $\begin{array}{c}0.0000^{* * *} \\
{[0.000]}\end{array}$ & $\begin{array}{c}0.0000^{* * *} \\
{[0.000]}\end{array}$ & $\begin{array}{c}0.0000^{* * *} \\
{[0.000]}\end{array}$ \\
\hline GDPc & & $\begin{array}{c}3.7659^{* * *} \\
{[0.000]}\end{array}$ & $\begin{array}{l}0.1903 \\
{[0.257]}\end{array}$ & $\begin{array}{c}5.7635^{* * *} \\
{[0.000]}\end{array}$ & $\begin{array}{l}-0.0125 \\
{[0.973]}\end{array}$ \\
\hline Constant & $\begin{array}{c}-1.2813^{* * *} \\
{[0.000]}\end{array}$ & $\begin{array}{c}-19.5049^{* * *} \\
{[0.000]}\end{array}$ & $\begin{array}{c}0.0000 \\
{[.]}\end{array}$ & $\begin{array}{c}-28.8950^{* * *} \\
{[0.000]}\end{array}$ & $\begin{array}{c}0.0000 \\
{[.]}\end{array}$ \\
\hline Industry Fixed Effects & No & No & No & Yes & Yes \\
\hline Time Dummies & No & No & Yes & No & Yes \\
\hline Observations & 432 & 369 & 369 & 369 & 369 \\
\hline Instruments & 53.0000 & 54.0000 & 41.0000 & 47.0000 & 52.0000 \\
\hline Groups & 67.0000 & 67.0000 & 67.0000 & 67.0000 & 67.0000 \\
\hline $\mathrm{AR}(1)$ & 0.0297 & 0.0589 & 0.0729 & 0.0677 & 0.0869 \\
\hline $\mathrm{AR}(2)$ & 0.6279 & 0.8618 & 0.7457 & 0.6935 & 0.5952 \\
\hline Hansen (p-Val) & 0.4350 & 0.3077 & 0.2563 & 0.1589 & 0.2212 \\
\hline
\end{tabular}

$p$-Value in parentheses

${ }^{*} p<0.1,{ }^{* * *} p<0.05,{ }^{* * *} p<0.01$

\section{CONCLUSION}

\subsection{Conclusion}

We have attempted to explore the impact of SPD on the financial performance of Indonesian firms and to investigate if being shariah compliant matters in the relationship between SPD and firms' financial performance. We did this by analysing data from 71 firms over the period 2010-2018. The dataset was mainly driven by the availability of data on SPD and included firms from different industries. We used Bloomberg's aggregated ESG disclosure scores, with a range of $0-100$. To avoid the potential problems of heterogeneity, serial autocorrelation and endogeneity, we employed the system GMM estimator. Upon estimation of our baseline model, we found that firms with higher disclosure scores tended to perform better financially. They also tended to have a better reputation, which led to higher gains. This is line with the findings of Beck, Frost, and Jones (2018), Cahan, De Villiers, Jeter, Naiker, and Van Staden (2016), Siregar and Bachtiar (2010), Teoh et al. (1998), Fauzi et al. (2007), Belkaoui and Karpik (1989), Naser et al. (2002) and Hadi and Budiana (2011), who also found that firms with greater disclosure of their sustainability practices performed better. Further, it was found that SCFs are at an advantage by being shariah compliant and that disclosure of sustainability performance increases the financial performance of such firms, unlike the nonshariah- compliant firms, where the impact was found to be negative. Larger firms 
and those with a greater capitalisation ratio were found to have better financial performance. Furthermore, firms with lower debt levels were also found to have stronger financial performance. The differences in the results might be driven by methodological anomalies in measuring SPD and financial performance, the differences in the research methods employed, the sample and the study period.

\subsection{Recommendations}

One of the main outcomes from the research is that simple involvement in sustainability-performance practices is insufficient, unless the information is disclosed properly. This leads to very important policy implications of the research. Firms in Indonesia should be encouraged to practise different sustainability activities and shariah compliance should be encouraged. In addition, information should be disclosed in financial statements so that it can reach all stakeholders. Firm management in Indonesia should consider sustainability practices and SPDs to be positive activities and consider them to be an investment rather than an obligation. Moreover, management should also focus on shariah compliance, which can further enhance their financial performance. Given the positive impact of sustainability practices on firm performance, customers should also recognize that firms that are involved in such practices are contributing to society and therefore encourage them.

One of the limitations of the study is that we used aggregated ESG scores to measure SPD; it could be argued that there should be a higher contribution of environmental, social and governance factors in the aggregated SPD scores. This could be explored in future research.

\section{REFERENCES}

Aerts, W. (2005) Picking up the Pieces: Impression Management in the Retrospective Attributional Framing of Accounting Outcomes. Accounting, Organizations and Society, 30, 493-517.

Arellano, M., \& Bond, S. (1991). Some Tests of Specification for Panel Data: Monte Carlo Evidence and an Application to Employment Equations. The Review of Economic Studies, 58(2), 277.

Azmi, W., Anwer, Z., Mohamad, S., \& Shah, M. E. (2019). The Substitution Hypothesis of Agency Conflicts: Evidence on Shariah Compliant Equities. Global Finance Journal, 41(April 2018), 90-103. https://doi.org/10.1016/j. gfj.2019.02.004

Barkemeyer, R., Comyns, B, Figge, F., et al. (2014) CEO Statements in Sustainability Reports: Substantive Information or Background Noise? Accounting Forum 38, 241-257.

Bartlett, R. P., \& Partnoy, F. (2018). The Misuse of Tobin's Q. SSRN Electronic Journal. https://doi.org/10.2139/ssrn.3118020.

Baumann-Pauly, D., Wickert, C, Spence, L. J., et al. (2013) Organizing Corporate Social Responsibility in Small and Large Firms: Size Matters. Journal of Business Ethics 115, 693-705. 
Beck, C., Frost, G., \& Jones, S. (2018). CSR Disclosure and Financial Performance Revisited: A Cross-country Analysis. Australian Journal of Management, 43(4), 517-537.

Belkaoui, A., \& Karpik, P. G. (1989). Determinants of the Corporate Decision to Disclose Social Information. Accounting, Auditing \& Accountability Journal, 2(1).

Berger, A. N., Klapper, L. F., \& Turk-Ariss, R. (2009). Bank Competition and Financial Stability. Journal of Financial Services Research, 35(2), 99-118.

Bernardi, C., \& Stark, A. W. (2018). Environmental, Social and Governance Disclosure, Integrated Reporting, and the Accuracy of Analyst Forecasts. The British Accounting Review, 50(1), 16-31.

Blundell, R., \& Bond, S. (1998). Initial Conditions and Moment Restrictions in Dynamic Panel Data Models. Journal of Econometrics, 87(1), 115-143. https:// doi.org/10.1016/S0304-4076(98)00009-8.

Cahan, S. F., De Villiers, C., Jeter, D. C., Naiker, V., \& Van Staden, C. J. (2016). Are CSR Disclosures Value Relevant? Cross-country Evidence. European Accounting Review, 25(3), 579-611.

Cahan, S. F., De Villiers, C., Jeter, D. C., Naiker, V., \& Van Staden, C. J. (2016). Are CSR Disclosures Value Relevant? Cross-Country Evidence. European Accounting Review, 25(3), 579-611. https://doi.org/10.1080/09638180.2015.1064 009.

Cho, S. J., Chung, C. Y., \& Young, J. (2019). Study on the Relationship between CSR and Financial Performance. Sustainability (Switzerland), 11(2), 1-26. https://doi. org/10.3390/su11020343.

Clark, G. L., \& Viehs, M. (2014). The Implications of Corporate Social Responsibility for Investors: An Overview and Evaluation of the Existing CSR Literature. Working paper. University of Oxford.

Davison, J., \& Skerratt, L. (2007) Words, Pictures and Intangibles in the Corporate Report. EAN 9781904574211. Retrieved from https://www.icas.com/technicalresources/publication-words-pictures-and-intangibles-in-the-corporatereport.

De Villiers, C., \& Van Staden, C. J. (2011). Where Firms Choose to Disclose Voluntary Environmental Information. Journal of Accounting and Public Policy, 30(6), 504525.

Dhaliwal, D. S., Li, O. Z., Tsang, A., \& Yang, Y. G. (2011). Voluntary Nonfinancial Disclosure and the Cost of Equity Capital: The Initiation of Corporate Social Responsibility Reporting. The Accounting Review, 86(1), 59-100. https:/doi. org/10.2308/accr.00000005.

Eccles, R. G., Ioannou, I., \& Serafeim, G. (2014). The Impact of Corporate Sustainability on Organizational Processes and Performance. Management Science, 60(11).

Eccles, R. G., Serafeim, G., Krzus, M. P. (2011), Market Interest in Nonfinancial Information. Journal of Applied Corporate Finance, 23(1), 113-127.

Fatemi, A. M., Fooladi, I. J., \& Tehranian, H. (2015). Valuation Effects of Corporate Social Responsibility. Journal of Banking and Finance, 59, 182-192.

Fatemi, A., Glaum, M., \& Kaiser, S. (2018). ESG Performance and Firm Value: The Moderating Role of Disclosure. Global Finance Journal, 38, 45-64. 
Fauzi, H., Mahoney, S. L., \& Abdul Rahman, A. (2007). The Link Between Corporate Social Performance and Financial Performance: Evidence from Indonesian Companies. Issues in Social and Environmental Accounting, 1(1), 149-159.

Goel, A. M., \& Thakor, A. V. (2016). Overconfidence, CEO Selection, and Corporate Governance. The Journal of Finance, 63(6), 2737-2784.

Healy, P. M., \& Palepu, K. G. (2001). Information Asymmetry, Corporate Disclosure, and the Capital Markets : A Review of the Empirical Disclosure Literature. Journal of Accounting and Economics, 31, 405-440.

Horváthová, E. (2010). Does Environmental Performance Affect Financial Performance? A Meta-analysis. Ecological Economics, 70(1), 52-59. https://doi. org/10.1016/j.ecolecon.2010.04.004.

Iheduru, N. G., \& Okoro, C. U. (2019). Sustainable Reporting and Profitability of Quoted Firms in Nigeria: A Multi-Dimensional Panel Data Study. Australian Finance \& Banking Review, 3(1), 1-10.

Jensen, M. C. (2002). Value Maximization, Stakeholder Theory, and the Corporate Objective Function. Business Ethics Quarterly, 12, 235-256.

Joo, S.-J., Nixon, D. and Stoeberl, P.A. (2011). Benchmarking with Data Envelopment Analysis: a Return on Asset Perspective. Benchmarking: An International Journal, 18(4), pp. 529-542.

Kartadjumena, E., Hadi, A. A., \& Budiana, N. (2011). The Relationship of Profit and Corporate Social Responsibility Disclosure (Survey on Manufacturing Industry in Indonesia). Proceedings of the 2nd International Conference on Business and Economic Research.

Kim, E.-H., \& Lyon, T. P. (2015). Greenwash vs. Brownwash: Exaggeration and Undue Modesty in Corporate Sustainability Disclosure. Organization Science, $26,705-723$.

KPMG, T. (2008). KPMG International Survey of Corporate Responsibility Reporting 2008. Amsterdam: KPMG.

KPMG, T. (2017). KPMG International Survey of Corporate Responsibility Reporting 2017. Retrieved from www.kpmg.com/crreporting.

Malik, M. (2015). Value-enhancing Capabilities of CSR: A Brief Review of Contemporary Literature. Journal of Business Ethics, 127, 419-438.

Margolis, J. D., Elfenbein, H. A., \& Walsh, J. P. (2009). Does it Pay to be Good and does it Matter? A Meta-analysis of the Relationship between Corporate Social and Financial Performance. Working paper. Harvard University.

Margolis, J.D., \& Walsh, J.P. (2001). People and Profits? The Search for a Link between a Company's Social and Financial Performance. Mahwah, NJ: Lawrence Erlbaum Associates.

Merkl-Davies, D. M., \& Brennan, N. M. (2007). Discretionary Disclosure Strategies in Corporate Narratives: Incremental Information or Impression Management? Journal of Accounting Literature, 26, 116-194.

Merton, R. C. (1987). A Simple Model of Capital Market Equilibrium with Incomplete Information. The Journal of Finance, XLII(3), 483-510. https://doi. org/10.1111/j.1540-6261.1987.tb04565.x.

Mirakhor, A. (2010). Whither Islamic Finance? Risk Sharing in An Age of Crises. Munich Personal RePEc Archive (MPRA). 
Mohammed, N. A., Saheed, Z., \& Oladele, O. K. (2016). Corporate Social Responsibility Disclosure and Financial Performance of Listed Manufacturing Firms in Nigeria. Research Journal of Finance and Accounting www. iiste. org ISSN, 2222-1697.

Naser, K., Al-Khatib, K., Karbhari, Y. (2002). Empirical Evidence on the Depth of Corporate Information Disclosure in Developing Countries: the Case of Jordan. International Journal on Corporate Management, 12(3 \& 4), 122- 152.

Noman, A. H. M., Gee, C. S., \& Isa, C. R. (2018). Does Bank Regulation Matter on the Relationship between Competition and Financial Stability? Evidence from Southeast Asian countries. Pacific Basin Finance Journal, 48, 144-161.

Noman, A. H., Gee, C. S., \& Isa, C. R. (2017). Does Competition Improve Financial Stability of the Banking Sector in ASEAN countries? An Empirical Analysis. PLoS ONE, 12(5), 1-27.

Porter, M. E., \& Kramer, M. R. (2011). Creating Shared Value. Harvard Business Review, 89, 62-77.

Qiu, Y., Shaukat, A., \& Tharyan, R. (2016). Environmental and Social Disclosures: Link with Corporate Financial Performance. The British Accounting Review, 48(1), 102-116.

Roodman, D. (2009). How to Do xtabond2: An Introduction to Difference and System GMM in Stata. Stata Journal, 9(1), 86-136. https://doi.org/10.2139/ ssrn.982943.

Siregar, S.V., \& Bachtiar, Y. (2010). Corporate Social Reporting: Empirical Evidence from Indonesia Stock Exchange. International Journal of Islamic and Middle Eastern Finance and Management, 3(3), 241-252.

Teoh, H. Y., Pin, F. W., Joo, T. T., \& Ling, Y. Y. (1998). Environmental DisclosuresFinancial Performance Link: Further Evidence from Industrialising Economy Perspective. Paper presented at the APIRA 98, Osaka, Japan.

Utz, S., \& Wimmer, M. (2014). Are They Any Good at All? A Financial and Ethical Analysis of Socially Responsible Mutual Funds. Journal of Asset Management, In Press.

Weber, O. (2017). Corporate Sustainability and Financial Performance of Chinese Banks. Sustainability Accounting, Management and Policy Journal, 8(3), 358-385.

Yahya, H. Y., \& Ghodratollah, B. (2014). Yahya, H. Y., \& Ghodratollah, B. (2014). The effect of disclosure level of CSR on corporate financial performance in Tehran stock exchange. International Journal of Accounting Research,1(11), 43-51. Yeganeh, Y. H., \& Barzegar, G. (2014). The Effect of Disclosure Level of Corporate Social Responsibility (CSR) on Corporate Financial Performance (CFP) in Tehran Stock Exchange. International Journal of Accounting Research, 42(1834), $1-18$. 


\section{APPENDIX A}

Table 1 Sample Composition by Year and Industry. Panel A: Composition by Year

\begin{tabular}{lc}
\hline 2010 & 42 \\
2011 & 53 \\
2012 & 54 \\
2013 & 58 \\
2014 & 59 \\
2015 & 70 \\
2016 & 71 \\
2017 & 71 \\
2018 & 70 \\
\hline Total Obs & 548 \\
\hline
\end{tabular}

\section{Panel B: Composition by Industry}

\begin{tabular}{lc}
\hline Automobiles \& Parts & 27 \\
Basic Resources & 138 \\
Chemicals & 8 \\
Construction \& Materials & 55 \\
Food \& Beverages & 65 \\
Healthcare & 32 \\
Industrial Goods \& Services & 35 \\
Media & 43 \\
Oil \& Gas & 4 \\
Personal \& Household Goods & 36 \\
Retail & 43 \\
Technology & 18 \\
Telecommunications & 26 \\
Utilities & 18 \\
\hline Total Obs & 548 \\
\hline
\end{tabular}




\section{APPENDIX B}

Table B1: Shariah-indexed Firms in Each Year

\begin{tabular}{|c|c|}
\hline Year & Shariah-indexed firms \\
\hline 2011 & 44 \\
\hline 2012 & 48 \\
\hline 2013 & 48 \\
\hline 2014 & 47 \\
\hline 2015 & 55 \\
\hline 2016 & 55 \\
\hline 2017 & 53 \\
\hline 2018 & 26 \\
\hline Total firms & 71 \\
\hline
\end{tabular}

\section{APPENDIX C}

Table A: Pooled Ordinary Least Squares (POLS) and Fixed Effects (FE) Regressions to Test the Need for GMM.

\begin{tabular}{|c|c|c|}
\hline & $\begin{array}{l}\text { ROA } \\
\text { OLS }\end{array}$ & $\begin{array}{c}\text { ROA } \\
\text { FE }\end{array}$ \\
\hline \multirow[t]{2}{*}{ ESG Disclosure Score } & 0.0851 & 0.1185 \\
\hline & {$[0.154]$} & [0.104] \\
\hline \multirow[t]{2}{*}{ Lnta } & $1.4391^{* * *}$ & 1.1264 \\
\hline & {$[0.005]$} & {$[0.394]$} \\
\hline \multirow[t]{2}{*}{ Cap_R } & $-0.0994^{* * *}$ & $-0.1153^{* * *}$ \\
\hline & {$[0.000]$} & {$[0.000]$} \\
\hline \multirow[t]{2}{*}{$\ln$ Debt } & $-1.0675^{* *}$ & -0.3313 \\
\hline & [0.012] & [0.487] \\
\hline \multirow[t]{2}{*}{ Inflat } & -0.2950 & -0.2659 \\
\hline & {$[0.287]$} & {$[0.348]$} \\
\hline \multirow[t]{2}{*}{ GDPGR } & $5.1713^{* * *}$ & $5.5557^{* * *}$ \\
\hline & {$[0.000]$} & {$[0.000]$} \\
\hline \multirow[t]{2}{*}{ Constant } & $-25.4239^{* * *}$ & -32.9911 \\
\hline & {$[0.000]$} & {$[0.138]$} \\
\hline Observations & 432 & 432 \\
\hline $\mathrm{R}^{2}$ & & 0.280 \\
\hline Breusch-Pagan test & 0.0000 & \\
\hline Wald test & & 0.0000 \\
\hline Wooldridge test for autocorrelation & 0.0379 & \\
\hline $\begin{array}{l}\text { Durbin-Wu-Hausman test (augmented regression } \\
\text { test) for endogeneity }\end{array}$ & 0.0000 & \\
\hline
\end{tabular}

$p$-values shown in parentheses. ${ }^{*} \mathrm{p}<0.1,{ }^{* *} \mathrm{p}<0.05,{ }^{* * *} \mathrm{p}<0.01$ 
Table B: DV Parameter of GMM or sys GMM Lies between FEM and OLS.

\begin{tabular}{lccc}
\hline & -1 & -2 & -3 \\
& OLS & FE & GMM \\
\hline L.Return on Assets & $0.6162^{* * *}$ & $0.1962^{* * *}$ & $0.6024^{* * *}$ \\
& {$[0.000]$} & {$[0.000]$} & {$[0.000]$} \\
ESG Disclosure Score & 0.0074 & -0.1046 & $0.0077^{* * *}$ \\
& {$[0.806]$} & {$[0.159]$} & {$[0.006]$} \\
Lnta & $1.3256^{* * *}$ & -1.3743 & $1.3099^{* * *}$ \\
& {$[0.000]$} & {$[0.276]$} & {$[0.000]$} \\
Capitalization Ratio & -0.0028 & -0.0170 & $0.0033^{*}$ \\
& {$[0.868]$} & {$[0.435]$} & {$[0.085]$} \\
lnDebt & $-1.1760^{* * *}$ & $-1.1396^{* * *}$ & $-1.1621^{* * *}$ \\
& {$[0.001]$} & {$[0.045]$} & {$[0.000]$} \\
Constant & -2.0185 & $43.0018^{* * *}$ & $-1.9927^{* * *}$ \\
& {$[0.249]$} & {$[0.004]$} & {$[0.000]$} \\
\hline Observations & 432 & 432 & 432 \\
R $^{2}$ & & 0.123 & \\
Instruments & & & 67.0000 \\
Groups & 67.0000 & 67.0000 & 67.0000 \\
Arellano-Bond: AR(1) & & & 0.0326 \\
Arellano-Bond: AR(2) & & & 0.6310 \\
Hansen Test (p-Val) & & & 0.4266 \\
\hline
\end{tabular}

$p$-value errors shown in parentheses.

" $p<0.1,{ }^{* *} p<0.05,{ }^{* * *} p<0.01$ 
This page is intentionally left blank 